\title{
MODEL PENDIDIKAN AGAMA ISLAM DALAM REHABILITASI PECANDU NARKOBA DI PONDOK PESANTREN TETIRAH DZIKIR SLEMAN YOGYAKARTA
}

\author{
Toha Machsun 1 \\ ISTAI YPBWI Surabaya
}

\begin{abstract}
ABSTRAK
Penelitian ini bertujuan mendeskripsikan dasar pemikiran pentingnya rehabilitasi pecandu narkoba menggunakan pendidikan agama Islam dan model Pendidikan Agama Islam yang digunakan untuk rehabilitasi pecandu narkoba di Pondok Pesantren Tetirah Dzikir Sleman Yogyakarta. Penelitian ini menggunakan pendekatan kualitatif jenis studi kasus. Hasil penelitian menunjukkan bahwa: (1) Dasar pemikiran pentingnya rehabilitasi pecandu narkoba menggunakan pendidikan agama Islam meliputi: alasan yuridis, religi, dan psikologis; (2) Model Pendidikan Agama Islam dalam rehabilitasi pecandu narkoba di pondok pesantren tersebut dilakukan melalui tiga tahapan: pertama pra pendidikan, kedua pendidikan agama Islam meliputi pembinaan shalat, puasa, dzikir, qiyamul lail, mandi taubat, ceramah agama, pembelajaran akidah akhlak, fiqih, baca tulis Al-Qur'an, dan ketiga adalah pendidikan pasca sembuh. Penulis berargumen bahwa selain pengobatan dan atau perawatan melalui rehabilitasi medis, proses penyembuhan pecandu narkoba dapat ditopang melalui pendekatan keagamaan yang diselenggarakan secara mandiri oleh masyarakat. Maka penulis merekomendasikan beberapa hal: pertama, perlu adanya dukungan moral dari orang tua kepada pasien, agar proses penyembuhan optimal. Kedua, pemerintah setempat harus mendukung penuh (terutama finansial) kegiatan di pondok pesantren Tetirah Dzikir. Ketiga, masyarakat harus menerima kembali klien yang sembuh sebagai bagian dari anggota masyarakat.

Kata Kunci: Pendidikan Agama Islam, Rehabilitasi, Pecandu Narkoba.
\end{abstract}

\section{ABSTRACT}

This study aims to describe the rationale for the importance of rehabilitation of drug addicts using islamic religious education and the islamic religious education model used for the rehabilitation of drug addicts in pondok pesantren Tetirah Dzikir Sleman Yogyakarta. This research uses a qualitative approach to the type of case study. The results showed that: (1) The rationale for the importance of rehabilitation of drug addicts using Islamic religious education, includes: juridical, religious, and psychological reasons; (2) The Islamic Religious Education Model in the rehabilitation of drug addicts is carried out in three stages: first, preeducation, second, Islamic education, includes guidance for prayer, fasting, dzikir, qiyamul lail, repentance bathing, religious lectures, learning akidah morals, figh, reading and writing the al-qur'an, and the third is post-recovery education. The author argues that in addition to treatment and / or treatment through medical rehabilitation, the healing process for drug addicts can be supported through a religious approach organized independently by the community. The author recommend several things: first, there needs to be moral support from parents to patients, so that the healing process is optimal. Second, the local government must fully support (especially financially) the activities at the pesantren. Third, the community must accept back clients who recover as part of the community.

Keywords: Islamic Religious Education, Rehabilitation, Drug Addicts 


\section{A. Pendahuluan}

Allah menciptakan manusia dalam bentuk yang paling sempurna. Namun dibalik kesempurnaannya manusia mempunyai kekurangan dan keterbatasan. Karena itu tidak jarang manusia terjerumus ke dalam lembah hitam, seperti pelacuran, dan menggunakan narkotika, psikotrapika, serta zat-zat adiktif yang diringkas dengan istilah Napza. ${ }^{1}$ Problematika individu dengan dirinya sendiri ialah kegagalan bersikap disiplin dan bersahabat dengan hati nuraninya sendiri, yakni hati nurani yang selalu mengajak, membimbing, dan menyeru kepada kebaikan serta kebenaran kepada Tuhannya sehingga muncul sikap was-was, ragu, prasangka buruk, lemah motivasi, dan tidak mampu bersikap mandiri dalam melakukan segala hal. ${ }^{2}$

Dalam konteks kecenderungan perilaku baik dan buruk seseorang, setidaknya ada dua faktor yang mempengaruhinya, yakni: pertama, faktor internal yang mengarahkan akal dan mengendalikan hawa nafsunya, dan kedua, faktor external yaitu berupa kondisi lingkungan sosial masyarakat, keluarga, dan pergaulan sehari-hari. Kedua faktor tersebut saling mempengaruhi satu dengan yang lainnya. Terjadinya aksi tindak kekerasan (violence) dan kenakalan remaja akhir-akhir ini merupakan fenomena yang seringkali kita jumpai. Bahkan kekerasan itu selalu menghiasi informasi media massa. Krisis multidimensi yang menimpa bangsa ini, salah satunya, karena adanya krisis moral. Krisis ini terjadi karena sebagian orang tidak mau mengindahkan tuntunan agama. Agama secara normatif mengajarkan kepada pemeluknya untuk berbuat baik, meninggalkan perbuatan-perbuatan maksiat dan munkarat. ${ }^{3}$ Tidak heran jika kemudian berbagai masalah dan penyakit sosial muncul, seperti kemiskinan, pengangguran, dan keterbelakangan karena sebagian warga masyarakat tidak dapat beradaptasi dengan tuntutan zaman.

Fenomena globalisasi tak bisa dipungkiri akan berdampak pada perubahan sikap mental masyarakat, khususnya di kalangan remaja dan anak muda. Hal ini terlihat pada berbagai gaya mereka, baik dalam cara berpakaian, bersikap, dan berbicara. Bahkan kecenderungan kehidupan global yang glamour dan mewah dapat membuat mereka kehilangan kontrol yang mengakibatkan konflik internal bahkan mengalami

\footnotetext{
${ }^{1} J u l i a n a$ Lisa dan Nengah Sutrisna, Narkoba, Psikotropika dan Gangguan Jiwa: Tinjauan Kesehatan dan Hukum. (Yogyakarta: Nuha Medika, 2013), 1.

${ }^{2}$ M. Hamdani Bakran Adz-Dzaky, Konseling dan Psikoterapi Islam (Yogyakata: Fajar Pustaka Baru, 2004), 1.

${ }^{3}$ Amir Said Az-Zaibairi, Manajemen Qalbu (Yogyakarta: Pustaka Pelajar, 2003), 5-6.
} 
interaksi negatif. ${ }^{4} \mathrm{Di}$ satu sisi ingin memuaskan hawa nafsu karena pengaruh lingkungan sosialnya, di sisi lain masih kuatnya tatanan nilai-nilai sosial, hal ini dapat berakibat stress dan frustasi.

Perilaku remaja yang menyimpang dalam berbagai dimensi seringkali berkaitan dengan penyalahgunaan narkotika, psikotropika dan bahan-bahan adiktif atau yang lebih dikenal dengan istilah narkoba. ${ }^{5}$ Narkoba, sebagai obat-obatan berbahaya, dapat menurunkan ambang untuk mengendalikan dorongan-dorongan (impulse) agresivitas baik fisik maupun seksual. ${ }^{6}$ Keadaan ini membuat penggunanya mudah melakukan perbuatan-perbuatan yang lepas kontrol dan bertentangan dengan nilai-nilai agama, norma-norma kesusilaan, dan hukum. Nata menyatakan bahwa penggunaan narkoba secara kontinyu dapat menimbulkan ketergantungan bagi pemakainya. Keadaan ini dapat berakibat bagi terjangkitnya penyakit psikologi lainnya, seperti malas bekerja, malas beribadah dan bahkan melakukan tindak kriminal untuk mendapat sebutir ekstasi. ${ }^{7}$

Peranan teman sebaya juga memiliki andil yang cukup besar dalam mekanisme terjadinya penyalahgunaan nakoba. Perkenalan anak terhadap narkoba ini dapat terjadi awal mulanya dari teman sebaya dan lama kelamaan anak itu berkeinginan untuk mencoba lagi, kemudian menjadi ketergantungan dengan narkoba. Apabila sudah seseorang sudah ketergantungan terhadap narkoba, maka jika tidak dipenuhi gejala-gejala sakit atau sakau akan muncul, yaitu ketagihan yang terus-menerus terhadap narkoba dan sulit dihentikan. Pecandu narkotika, dalam keadaan sakau, merasa tidak tahan lagi dan berupaya dengan cara apapun tanpa menghiraukan resiko yang akan menimpanya untuk mendapatkan kembali kebutuhan barang-barang tersebut. $^{8}$

Motivasi para pengguna narkoba di antaranya adalah membuktikan keberanian melakukan hal-hal yang membahayakan, menentang atau melawan suatu otoritas, mempermudah penyaluran atau perbuatan seks dan kebanyakan dari pemakainya

\footnotetext{
4 Zaini Tamin AR dan Subaidi, "Implementasi Segregasi Kelas Berbasis Gender dalam Menaggulangi Interaksi Negatif Siswa di SMP Al-Falah Ketintang Surabaya", Al Hikmah : Jurnal Studi Keislaman, Vol. 9, No. 1 (2019): 30-43.

${ }^{5}$ Madjid Tawil, dkk., Narkoba Dikenal untuk Dijauhi (Surabaya: BNP JATIM, 2005), 1.

6 Dadang Hawari, Al-Qur'an dan Ilmu Kedokteran Jiwa dan Kesehatan Jiwa (Yogyakarta: Dana Bhakti Prima Yasa, 2007), 247.

${ }^{7}$ Abuddin Nata Ilmu Kalam Filsafat dan Tasawuf (Jakarta: PT. Raja Grafindo Persada, 2001), 192.

8 Dadang Hawari, Do'a dan Dzikir sebagai Pelengkap Terapi Medis (Yogyakarta: PT. Dana Bakti Prima Yasa, 2003), 55.
} 
adalah sebagai pelarian dari rasa frustasi dan kegelisahan masalah. ${ }^{9}$ Kecanduan narkotika, obat-obatan terlarang, dan zat adiktif lain merupakan kasus yang amat merisaukan kita, dari tahun ke tahun pengguna narkoba ini bukan semakin menurun malah cenderung meningkat. Penelitian Hawari membuktikan bahwa pada tahun 1975 catatan pemerintah menunjukkan ada 5.000 orang tersangkut kasus sebagai pengguna narkoba. Tetapi pada tahun 1990 jumlahnya telah mencapai 8.500 orang, pada tahun 1995 telah mencapai 13.000 orang. Pada tahun 1998 Hawari menemukan "dark number" artinya setiap orang pengguna narkoba ini sebenarnya memiliki teman sebanyak 10 orang pengguna narkoba. Jadi jumlah sebenarnya adalah 10 kali lipat dari data yang ada. ${ }^{10}$

Hasil penelitian Badan Narkotika Nasional bekerjasama dengan Pusat Penelitian Kesehatan Universitas Indonesia, tahun 2008, penyalahgunaan narkoba sebanyak 2,23\% setara dengan 4 juta orang. Hasil penelitian tahun 2011 menunjukkan angka prevalensi penyalahgunaan narkoba di Indonesia $2,2 \%$ berarti adanya penurunan. Penurunan ini mengindikasikan upaya pencegahan dan pemberantasan penyalahgunaan dan peredaran gelap narkoba di Indonesia. ${ }^{11}$

Pemerintah Indonesia telah melakukan berbagai upaya pemberantasan narkoba yakni dengan menerbitkan UU No. 35 Th. 2009 tentang narkotika, membentuk Badan Narkoba Nasional (BNN), dan juga mengeluarkan Instruksi Presiden No. 12 Th. 2011 tentang pelaksanaan JAKSTRANAS bidang Pemberantasan Penyalahgunaan dan Peredaran Gelap Narkoba (P4GN) tahun 2011-2015 yang mendorong segenap elemen bangsa, pemerintah pusat dan daerah, pemangku kepentingan dan masyarakat untuk lebih aktif dan agresif lagi dalam memerangi kejahatan narkoba.

Larangan dan bahaya pemakaian narkoba baik melalui ceramah agama, media cetak maupun media elektronik sudah sering disampaikan, tetapi penggunaan dan peredaran narkoba ini masih tetap berlanjut dan malah semakin parah. Padahal sudah jelas dalam Al-Qur'an, Allah SWT berfirman dalam surat Al-Maidah ayat 90 yang artinya:

Artinya: "Hai orang-orang yang beriman, sesungguhnya (meminum) khamar, berjudi, (berkorban untuk) berhala, mengundi nasib dengan panah adalah termasuk perbuatan syaitan. Maka jauhilah perbuatan-perbuatan itu agar kamu mendapat keberuntungan". ${ }^{12}$

\footnotetext{
${ }^{9}$ Kharisudin Aqib, Inabah Jalan Kembali dari Narkoba, Stress dan Kehampaan Jiwa (Surabaya: PT. Bina Ilmu, 2005), 148.

${ }^{10}$ Hawari, Do'a dan Dzikir sebagai Pelengkap Terapi Medis, 133.

${ }^{11}$ Badan Narkotika Nasional, Mencegah Lebih Baik dari pada Mengobati (Jakarta: Team BNN, 2013), 3.

12 Depag RI, Alqur'an Dan Terjemahnya (Bandung: SYGMA, 2009), 123.
} 
Islam telah memberikan penjelasan bahwa meminum khamar adalah termasuk perbuatan syaitan. Syaitan adalah musuh umat Islam yang jelas, dan Allah pun memberikan perintah kepada umat Islam agar menjauhi perbuatan yang demikian itu agar kita termasuk golongan yang beruntung. Secara eksplisit ayat di atas juga menjelaskan bahwa khamr harus benar-benar dijauhi. Hal ini sama dengan posisi narkoba sebagai bahan yang bisa memabukan. Sebagai obat-obatan yang memiliki daya agar para pemakainya tidak sadarkan diri, narkoba juga memiliki kekuatan yakni membuat candu bagi para pemakainya.

Hasil survei BNN tahun 2009 menunjukkan bahwa rata-rata usia pertama kali menyalahgunakan narkotika adalah usia yang sangat muda yaitu 12-15 tahun, dan semakin tinggi jenjang pendidikan, semakin tinggi pula angka penyalahgunaan narkotika. ${ }^{13}$ Berbagai usaha pencegahan dan penyadaran terus-menerus dilakukan agar mereka kembali ke jalan yang benar, dan akhirnya terciptalah kehidupan yang bersih, tentram, dan bahagia sebagai manifestasi dari kehidupan yang ma'ruf secara Islami. Karena itulah mereka harus diseru menuju jalan yang lurus dengan cara bijaksana sehingga dapat menimbulkan kesadaran untuk selalu berpikiran dan berperilaku positif.

Pendidikan agama Islam bagi pecandu dan mantan pecandu narkoba sangat penting dilakukan untuk menghilangkan kondisi kritis yang dihadapai oleh para mantan pecandu narkoba dengan berbagai macam gangguan kejiwaan akibat pengaruh mengkomsumsi narkoba. Dasar pemikiran pentingnya pendidikan agama ini karena satu-satunya jalan untuk kembali menjadi manusia yang mulia di sisi Allah hanyalah dengan mengamalkan agama secara sempurna dengan mengikuti sunnah Nabi Muhammad SAW. Pendidikan ini mengajak mereka kembali ke jalan yang benar melalui bimbingan agama dengan berbagai macam metode dan yang paling menonjol di antara amalan itu di Panti Rehabilitasi Pondok Tetirah Dzikir Berbah Sleman Yogyakarta adalah amalan dzikir Tarekat Qodiriah Naqsyabandiyah.

Hingga studi ini dilakukan pecandu narkoba yang sedang menjalani proses rehabilitasi di pondok pesantren ini ada 60 orang, sedangkan yang telah sembuh sejak tahun 2015 sekitar 46 orang, di antara mereka sudah dikembalikan ke masyarakat dan sebagian lainnya menjadi relawan pondok membantu proses rehabilitasi pasien yang sedang menjalani pendidikan. ${ }^{14}$ Fenomena tersebut menunjukkan bahwa Panti Rehabilitasi Pondok Tetirah Dzikir telah menampilkan diri sebagai sarana pendidikan

${ }^{13}$ Badan Narkotika Nasional, Mencegah Lebih Baik dari pada Mengobati, 5.

14 Ustadz Ardhiyan Akhsa, Wawancara, Sleman, 15 Januari 2020. 
agama Islam bagi pecandu dan mantan pecandu narkoba. Keberhasilan Panti Rehabilitasi Pondok Tetirah Dzikir dalam meminimalisir bahaya narkoba di kalangan remaja menarik untuk diteliti. Karena itu, penjelasan di atas mendorong penulis untuk melakukan penelitian model pendidikan agama Islam dalam rehabilitasi pecandu narkoba di panti Rehabilitasi Pondok Tetirah Dzikir Berbah Sleman Yogyakarta. Oleh karena itu masalah yang diajukan dalam studi ini: (1) Bagaimana dasar pemikiran pentingnya rehabilitasi pecandu narkoba menggunakan pendidikan agama Islam; (2) bagaimana model Pendidikan Agama Islam dalam rehabilitasi pecandu narkoba; dan (3) apa saja kendala proses Pendidikan Agama Islam dalam rehabilitasi pecandu narkoba di Pondok Pesantren Tetirah Dzikir Berbah Sleman Yogyakarta? Uraian berikut merupakan jawaban ketiga masalah tersebut.

Studi tentang rehabilitasi pecandu narkoba menggunakan pendidikan keagamaan Islam telah sering dilakukan, di antaranya: Alhamuddin ${ }^{15}$ menemukan bahwa Kurikulum rehabilitasi korban penyalahgunaan NAPZA di Pondok Inabah VII dikembangkan dengan pendekatan tasawwuf. Tahapan implementasi kurikulum: (1) Takhalli, menyucikan diri dari dosa yang mencemari jiwa, baik jasmani maupun rohani; (2) Tahalli, menghiasi diri dengan perilaku baik, baik lahir maupun batin; (3) Tajalli, hasil dari takhalli dan tahalli. Tajalli adalah tujuan akhir rehabilitasi. Selanjutnya, ketiga konsep tersebut diterapkan dalam tiga kegiatan inti; Mandi Taubat (orang yang membasuh badan untuk membersihkan diri dari dosa), Shalat dan dzikir. Selain itu, peran pemandu juga sangat menentukan selama proses penyembuhan. Metode Inabah itu unik; karena tidak menggunakan obat atau jamu kimia. Alternatif terapi agama digunakan untuk pemulihan korban narkoba, baik fisik, mental, sosial maupun spiritual.

Lebih detail, Firdaus, ${ }^{16}$ menemukan bahwa pada instansi pemerintah dan lembaga swadaya masyarakat, program therapeutif community (TC) menjadi bagian penting dalam Rehabilitasi Sosial kepada klien. Penyalahguna narkoba, dengan dukungan kekeluargaan dan interaksi antar klien / pasien yang harmonis dalam program rehabilitasi sosial merupakan faktor penting untuk perbaikan atau penyembuhan pasien / klien korban penyalahgunaan narkoba. Detoksifikasi

${ }^{15}$ Alhamuddin, "Merawat Jiwa Menjaga Tradisi: Dzikir dan Amal Thariqah Qadiriyah Naqsabandiyah dalam Rehabilitasi Korban Napza Sebagai Terapis Ala Islam Nusantara”, Sosial Budaya: Media Komunikasi Ilmuilmu Sosial dan Budaya, Vol. 12, No. 1 (Januari-Juni 2015).

16 Ismet Firdaus, "Meta Analisis Hasil Penelitian Model-Model Rehabilitasi Narkoba oleh Lembaga Pemerintah, Masyarakat dan Pesantren di Jabodetabek", EMPATI: Jurnal Ilmu Kesejahteraan Sosial, Vol. 4 No. 1 (Juni 2015). 
(pengeluaran racun obat untuk pasien / klien) yang ada di instansi pemerintah dan LSM hampir sama, sedangkan di pesantren detoksifikasi berbeda-beda, misalnya dengan minum air yang telah diberi do'a. Sementara itu, program rehabilitasi di pesantren lebih menekankan pada peningkatan hubungan klien dengan Tuhan melalui amalan ritual ibadah yang menurutnya berimplikasi pada penyembuhan klien penyalahguna narkoba.

Rokib ${ }^{17}$ menemukan bahwa Pondok Sapu Jagad Yayasan Pondok Pesantren Raudlatul Ulum Kencong, Kepung, Kediri merupakan salah satu pesantren yang melakukan model psikoterapi religi kepada pecandu narkoba. Pesantren tersebut berada di lingkungan penganut Terekat Qadiriyah Nasyahbandiyah. Dalam pandangan Terekat Qadiriyah Naqsyabandiyah, jiwa (nafs) adalah kelembutan (lathifah) yang bersifat ketuhanan (rabbaniyah). Lathifah ini sebelum bersatu dengan jasmani manusia disebut dengan al-ruh, dan jiwa adalah ruh yang telah menyatu dengan jasad yang menimbulkan potensi kesadaran (ego). Dengan demikian sembuhnya pecandu narkoba juga karena faktor lingkungan, dimana pecandu itu pindah domisili serta didukung oleh faktor terkait dengan kesehatan jiwa dan fisik. Selain hal tersebut, sadarnya pecandu narkoba juga disebabkan karena bangkitnya kembali potensi-potensi dalam diri manusia, seperti fitrah, nafsu baik, akal, atau niat baik.

Secara khusus, Lestari, ${ }^{18}$ menjelaskan bahwa pembinaan dan penyadaran korban penyalahgunaan NAPZA dapat dilakukan melalui metode Zikrullah, yang dimaksud sebagai upaya untuk menenangkan hati, menyembuhkan segala penyakit hati, membersihkan hati, dan sebagai sarana meningkatkan keimanan kepada Allah. Materi rehabilitasi meliputi mandi malam atau bertaubat, shalat wajib dan sunnah, dzikir, membaca Al-quran, riyadlah, pengajian mingguan dan bulanan, dan pembelajaran tentang hal-hal ilmiah seperti fiqh, tauhid, akhlaq, dan tashawuf.

Muhtar $^{19}$ mempertimbangkan bahwa upaya mengatasi korban penyalahgunaan narkoba di Pondok Pesantren Inabah Surabaya mengutamakan aspek spiritual Islami yang bersumber dari Al-quran, al-Sunah, dan fatwa para ulama, khususnya para ulama Tarekat Qodiriyah wa-Naqsabandiyah. Cara ini merupakan salah satu pendekatan

17 Abdur Rokib "Rehabilitasi Pecandu Narkoba dan Stress di Pondok Sapu Jagad Yayasan Pesantren Raudlatul Ulum Kencong, Kepung, Kediri, Jawa Timur," Tesis----.--Pascasarjana IAIN Sunan Ampel Surabaya, 2009.

18 Puji Lestari, "Metode Terapi dan Rehabilitasi Korban NAPZA di Pondok Pesantren Suryalaya Tasikmalaya”, Socia: Jurnal Ilmu Sosial, Vol. 10, No. 2 (September 2013).

19 Muhtar, "Pendekatan Spiritual dalam Rehabilitasi Sosial Korban Penyalahgunaan Narkoba di Pesantren Inabah Surabaya”, INFORMASI, Vol. 19, No. 3, (September - Desember, 2014). 
dalam sistem rehabilitasi penyalahgunaan narkoba. Pendekatan spiritual islami ini juga dikenal dengan istilah "Psikoterapi Islami", yaitu proses pengobatan dan rehabilitasi bagi penyakit atau gangguan mental, spiritual, moral, dan fisik korban penyalahgunaan NAPZA melalui bimbingan dan tuntunan dari Allah SWT, Nabi / Rasul, dan Ahli WarisNya. Oleh karena itu, pendekatan spiritual Islam ini terbuka luas untuk dikembangkan terus.

Sementara, $\mathrm{Ali}^{20}$ melalui studi kepustakaannya mengekplorasi tiga model pencegahan kecanduan narkoba dari perspektif teologis Islam dalam kajian ini, dua di antaranya adalah model pencegahan berdasarkan pemahaman masyarakat yang berakar pada budaya malu, sementara model ketiga, yang disebut Millati Islami, dipraktikkan di AS, didasarkan pada pemahaman Islam tentang tawba (pertobatan). Selain itu, obat-obatan dan kecanduan dalam kitab suci, serta sikap masyarakat muslim abad pertengahan terhadap mereka, dieksplorasi. Secara keseluruhan, modelmodel yang dibahas dalam artikel ini menunjukkan bahwa teologi Islam memiliki alat intelektual dan teoritis untuk mengembangkan model-model kecanduan teologis yang lengkap.

Selanjutnya, Rajab ${ }^{21}$ mengungkap bahwa psikoterapi Islam adalah metodologi yang didasarkan pada Al-quran dan Sunnah. Al-quran dan Sunnah adalah sumber pengetahuan. Psikoterapi Islam memberikan solusi untuk gangguan jiwa. Pondok Pesantren Suryalaya telah memberikan pembinaan kepada pasien yang kecanduan narkoba agar bisa sembuh. model psikoterapi Islami yang diterapkan di pesantren adalah pendekatan berbasis tasawuf. Tasawuf adalah cara untuk lebih dekat dengan Tuhan. Melalui pendekatan tersebut, pasien yang kecanduan obat dapat disembuhkan. Jika pasien menyadari bahwa Tuhan menjawab do'a mereka melalui ibadah, maka rasa berdosa dan bersalah secara bertahap akan hilang. Pesantren tersebut telah menerapkan psikoterapi Islam dengan pendekatan Tasawuf QadiriyyahNaqsyabandiyyah. Melalui pendekatan tersebut, pasien berhasil sembuh total.

Penelitian-penelitian di atas menunjukkan bahwa rehabilitasi pecandu narkoba dengan pendekatan spiritual menarik dikaji. Penelitian ini berupaya untuk menguatkan penelitian-penelitian sebelumnya. Apabila beberapa penelitian sebelumnya membahas terhkait bagaimana pendekatan spritual dapat membantu rehabilitasi pecandu

\footnotetext{
${ }^{20}$ Mansur Ali, "Perspectives on Drug Addiction in Islamic History and Theology", Religions, Vol. 5 (2014).

21 Khairunnas Rajab, "Methodology of Islamic psychotherapy in Islamic boarding school Suryalaya Tasik Malaya", IJIMS, Indonesian Journal of Islam and Muslim Societies, Volume 4, Number 2 (December 2014).
} 
narkoba, maka penelitian ini lebih mengrucut pada sisi pedagogis. Penelitian ini lebih memfokuskan pada dasar pemikiran pentingnya rehabilitasi pecandu narkoba menggunakan pendidikan agama Islam dan model Pendidikan Agama Islam dalam rehabilitasi pecandu narkoba di Pondok Pesantren Tetirah Dzikir Berbah Sleman Yogyakarta.

\section{B. Titik Simpul Pendidikan Agama Islam dan Rehabilitasi Pecandu Narkoba}

Dasar pendidikan Islam di lembaga pendidikan di Indonesia dapat ditinjau dari aspek yuridis, religus, dan psikologis. ${ }^{22}$ Dasar yuridis meliputi: (1) dasar ideal tertuang dalam sila pertama pancasila: ketuhanan yang maha Esa; dan (2) dasar struktural tercantum dalam bab XI pasal 29 ayat 1 dan 2 UUD 1945: Negara berdasarkan atas Ketuhanan Yang Maha Esa, menjamin kemerdekaan tiap-tiap penduduk untuk memeluk agama masing-masing dan beribadah sesuai kepercayaannya. Dasar religus, yakni keyakinan bahwa pendidikan agama merupakan perintah Tuhan dan perwujudannya merupakan ibadah kepadaNya sebagaimana QS. An Nahl [16] :125 dan QS. Al Imran [3]:104, dan Al Hadis : "Sampaikanlah ajaran kepada orang lain walaupun hanya sedikit." (Diriwayatkan oleh Imam Bukhari: 3641). Dasar Psikologis, dasar yang berhubungan dengan aspek kejiwaan kehidupan bermasyarakat. Bahwa semua manusia di dunia ini selalu membutuhkan pegangan hidup yang disebut agama ${ }^{23}$.

Pendidikan Agama Islam (PAl) bertujuan menumbuhkan dan meningkatkan keimanan melalui pemberian dan pemupukan pengetahuan, penghayatan, pengamalan serta pengalaman peserta didik tentang agama Islam, sehingga menjadi manusia muslim yang terus berkembang dalam hal keimanan, ketakwaannya, berbangsa dan bernegara, serta untuk dapat melanjutkan pada jenjang pendidikan yang lebih tinggi. ${ }^{24}$ Aspek tujuan PAl meliputi tujuan: jasmaniah, rohaniah, akal, dan tujuan sosial. ${ }^{25}$ Tujuan akhir PAI menjadi manusia yang sempurna, dengan ciri-ciri sehat jasmani dan kuat, akalnya cerdas serta pandai dan hatinya penuh iman kepada Allah. ${ }^{26}$

PAl sebagai ilmu dan amaliyah mempunyai ruang lingkup yang luas dijadikan landasan spiritual dan apabila dipraktekkan dalam kehidupan sehari-hari maka

\footnotetext{
22 Abdul Majid dan Dian Andayani, Pendidikan Agama Islam Berbasis Kompetensi: Konsep dan Implementasi Kurikulum 2004 (Bandung: PT Remaja Rosdakarya, 2006), 132-134.

${ }^{23}$ Zuhairini, dkk., Filsafat Pendidikan Islam (Jakarta: Bumi Aksara, 2009), 32.

${ }^{24}$ Majid dan Andayani Pendidikan Agama Islam Berbasis Kompetensi, 135.

${ }^{25}$ Ramayulis, Ilmu Pendidikan Islam (Jakarta: Kalam Mulia, 2013), 225.

${ }^{26}$ Ahmad Tafsir, Ilmu Pendidikan Islami (Bandung: PT Remaja Rosdakarya, 2012), 63.
} 
kehidupan manusia akan baik. Urutan prioritas pendidikan Islam dalam upaya pembentukan kepribadian muslim adalah: (a) pendidikan keimanan kepada Allah; (b) Pendidikan akhlakul karimah; (c) Pendidikan ibadah. ${ }^{27}$ Adapun teknik mengajar menurut Nawawi sebagaimana dikutip Ramayulis ${ }^{28}$ terdiri dari: (1) mendidik melalui keteladanan; (2) mendidik melalui kebiasaan; (3) mendidik melalui nasihat dan cerita; (4) mendidik melalui disiplin; (5) mendidik melalui partisipasi; dan (6) mendidik melalui pemeliharaan.

Dari kerangka dan proses pedagogisnya, maka sebagian aspek serupa dengan proses rehabilitasi pecandu narkoba. Secara sederhana, rehabilitasi berarti pemulihan (perbaikan atau pembetulan) seperti sedia kala; pengembalian nama baik secara hukum, pembaharuan kembali. ${ }^{29}$ Rehabilitasi merupakan upaya memulihkan dan mengembalikan kondisi mantan penyalahguna/ketergantungan narkoba kembali sehat dan psikologik, sosial, dan spiritual/agama (keimanan). Dengan kondisi seperti tersebut diharapkan mereka akan kembali berfungsi secara wajar dalam kehidupannya sehari-hari baik di rumah, di sekolah/ kampus, di tempat kerja dan di lingkungam sosialnya. ${ }^{30} \mathrm{Jadi}$, rehabilitasi merupakan tahapan penting bagi pecandu narkoba untuk lepas dari ketergantungan narkoba. Pemulihan ini merupakan proses panjang dan sering diibaratkan perjalanan dari pikiran (adiktif) ke hati. Program rehabilitasi ini menurut Kadarmanta dikenal sebagai "konversi hati dan perubahan internal". ${ }^{31}$

Kewajiban menjalani pengobatan dan perawatan bagi pecandu narkotika diatur dalam undang-undang nomor 35 tahun 2009 tentang narkotika dalam pasal 54, pasal 56, pasal 57, dan pasal 58: Pecandu Narkotika dan korban penyalahgunaan Narkotika wajib menjalani rehabilitasi medis dan rehabilitasi sosial (pasal 54). Rehabilitasi medis pecandu Narkotika dilakukan di rumah sakit yang ditunjuk oleh Menteri (Pasal 56 ayat 1). Lembaga rehabilitasi tertentu yang diselenggarakan oleh instansi pemerintah atau masyarakat dapat melakukan rehabilitasi medis pecansu narkotika setelah mendapat persetujuan Menteri (Pasal 56 ayat 2). Selain melalui pengobatan dan/atau rehabilitasi medis, penyembuhan Pecandu Narkotika dapat diselenggarakan oleh instansi pemerintah atau masyarakat melalui

\footnotetext{
27 Zuhairini, dkk., Filsafat Pendidikan Islam, 155-158.

28 Ramayulis, Ilmu Pendidikan Islam, 286.

29 Tim Prima Pena, Kamus Ilmiah Populer (Surabaya: Gitamedia Press, 2006), 404.

30 Dadang Hawari, Penyalahguna dan Ketergantungan NAZA (Narkotika, Alkohol, dan Zat Adiktif) (Jakarta: Penerbit FKUI), 132.

31 Kadarmanta, Narkoba Pembunuh Karakter Bangsa (Jakarta: PT Forum Media Utama), 180
} 
pendekatan keagamaan dan tradisional (Pasal 57). Rehabilitasi sosial mantan pecandu Narkotika diselenggarakan baik oleh instansi pemerintah maupun oleh masyarakat.

Tahapan utama proses rehabilitasi meliputi: tahap detoksifikasi, stabilisasi, dan rehabilitasi. ${ }^{32}$ Tahap detoksifikasi terapi lepas narkoba (withdrawal syndrome) dan terapi fisik yang ditujukan untuk menurunkan dan menghilangkan racun dari tubuh, mengurangi akibat putus narkoba serta mengobati komplikasi mental penderita. Tahap stabilisasi suasana mental dan emosional penderita sehingga gangguan jiwa yang menyebabkan perbuatan penyalahgunaan narkoba dapat diatasi sehingga penderita secara bertahap dapat menyesuaikan diri dengan situasi perawatan dan situasi sosialnya. Tahap rehabilitasi atau pemulihan keberfungsian fisik, mental dan sosial penderita seperti bersekolah belajar bekerja serta bergaul secara normal dengan lingkungan sosial selanjutnya. Menurut BNN proses perawatan dan penderita ketergantungan narkoba merupakan proses yang panjang mulai dari detoksifikasi, pengobatan dan pemulihan kondisi fisik, pemberian dukungan psikologis melalui konseling psikologis, terapi perilaku (behaviour modification) bila penderita menunjukkan gejala penyimpangan prilaku, intervensi psikiatris rehabilitasi sosial, rehabilitasi vokasional serta upaya pembinaan lanjutan baik dalam keluarganya, dilingkungan kerjanya, atau dalam situasi yang sengaja diciptakan yang disebut therapeutic community. ${ }^{33}$

\section{Dasar Rehabilitasi berbasis PAl di Pondok Pesantren Tetirah Dzikir}

Berdasarkan hasil wawancara dengan Ustadz Muhammad Ismail, diperoleh data bahwa pendidikan agama Islam yang dilakukan di Panti Rehabilitasi Pondok Tetirah Dzikir untuk rehabilitasi pecandu narkoba didasarkan pada Undang-Undang No 22 Tahun 1997 pada pasal 49 yang berbunyi bahwa selain pengobatan dan atau perawatan melalui rehabilitasi medis proses penyembuhan pecandu narkotika dapat diselenggarakan oleh masyarakat melalui pendekatan keagamaan dan tradisonal. ${ }^{34}$

Pendidikan agama Islam bagi mantan pecandu narkoba sangat penting dilakukan untuk menghilangkan kondisi kritis yang dihadapai oleh para mantan pecandu narkoba dengan berbagai macam gangguan kejiwaan akibat pengaruh mengkomsumsi narkoba. Dalam hal ini KH. Muhammad Trihardana, menjelaskan:

\footnotetext{
32 Badan Narkotika Nasional, Mencegah Lebih Baik daripada Mengobati, 124.

33 Ibid.

34 Ustadz Muhammad Ismail, Wawancara, Sleman, 11 Januari 2020.
} 
"Pendidikan Islam di pondok pesantren ini mengajak para pecandu narkoba untuk kembali ke jalan yang benar melalui bimbingan agama dengan berbagai macam metode dan yang paling menonjol di antara amalan itu adalah amalan dzikir Tarekat Qodiriah Naqsyabandiyah. Karena satu-satunya jalan untuk kembali menjadi manusia yang mulia di sisi Allah hanyalah dengan mengamalkan agama secara sempurna dengan mengikuti sunnah Nabi Muhammad SAW. ${ }^{35}$

Allah swt berfirman dalam surat Al-Maidah ayat 90 yang artinya: "Hai orangorang yang beriman, sesungguhnya (meminum) khamar, berjudi, (berkorban untuk) berhala, mengundi nasib dengan panah adalah termasuk perbuatan syaitan. Maka jauhilah perbuatan-perbuatan itu agar kamu mendapat keberuntungan". Menurut KH. Muhammad Trihardana, pengasuh pondok pesantren Tetirah Dzikir Sleman:

"Ayat tersebut menegaskan bahwa meminum khamar adalah termasuk perbuatan syaitan. Syaitan adalah musuh umat Islam yang jelas, dan Allah pun memberikan perintah kepada umat Islam agar menjauhi perbuatan yang demikian itu agar kita termasuk golongan yang beruntung. ." 36

Secara eksplisit menurut pengasuh pondok ayat di atas juga menjelaskan bahwa khamr harus benar-benar dijauhi. Hal ini sama dengan posisi narkoba sebagai bahan yang bisa memabukan. Sebagai obat-obatan yang memiliki daya agar para pemakainya tidak sadarkan diri, narkoba juga memiliki kekuatan yakni membuat candu bagi para pemakainya.

Menurut hemat penulis bahwa dasar pendidikan Islam di sekolah-sekolah pada umumnya juga dapat menjadi dasar pemikiran dilakukannya pendidikan Islam sebagai upaya rehabilitasi pecandu narkoba di Pondok pesantren ini, yaitu bahwa pendidikan agama Islam baik di sekolah maupun di pondok pesantren dapat didasarkan pada aspek yuridis, religus, dan psikologis sebagaimana dikemukakan Majid dan Andayani ${ }^{37}$

Dasar yuridis meliputi: (1) dasar ideal tertuang dalam sila pertama pancasila: ketuhanan yang maha Esa; dan (2) dasar struktural tercantum dalam bab XI pasal 29 ayat 1 dan 2 UUD 1945: Negara berdasarkan atas Ketuhanan Yang Maha Esa, menjamin kemerdekaan tiap-tiap penduduk untuk memeluk agama masing-masing dan beribadah sesuai keperca-yaannya.

Sementara, dasar religus yakni keyakinan bahwa pendidikan agama merupakan perintah Tuhan dan perwujudannya merupakan ibadah kepadaNya sebagaimana QS. An Nahl [16] :125: yang artinya "Serulah (manusia) kepada jalan

\footnotetext{
35 KH. Muhammad Trihardana, Wawancara, Sleman, 11 Januari 2020.

${ }^{36} \mathrm{KH}$. Muhammad Trihardana, Wawancara, Sleman, 22 Januari 2020.

${ }^{37}$ Majid dan Andayani, Pendidikan Agama Islam, 132-134.
} 
Tuhan-mu dengan hikmah dan pelajaran yang baik dan bantahlah mereka dengan cara yang baik. Sesungguhnya Tuhanmu Dialah yang lebih mengetahui tentang siapa yang tersesat dari jalan-Nya dan Dialah yang lebih mengetahui orang-orang yang mendapat petunjuk".

Selain ayat tersebut, juga dapat didasarkan pada perintah Allah kepada hambanya untuk menyuruh kepada perbuatan-perbuatan kebaikan (ma'ruf) dan mencegah kemungkaran sebagaimana QS. Al Imran [3]:104: yang artinya: “dan hendaklah ada di antara kamu segolongan umat yang menyeru kepada kebajikan, menyuruh kepada yang ma'ruf dan mencegah dari yang munkar, merekalah orangorang yang beruntung."

Sedangkan, dasar psikologis, yaitu dasar yang berhubungan dengan aspek kejiwaan kehidupan bermasyarakat. Bahwa semua manusia di dunia ini selalu membutuhkan pegangan hidup yang disebut agama, ${ }^{38}$ semakin kuat keyakinan agama seseorang semakin kecil kemungkinan terlibat kasus narkoba. Keyakinan inilah yang menjadi dasar rehabilitasi pecandu narkoba menggunakan pendekatan agama di Pondok Pesantren Tetirah Dzikir Berbah Sleman Yogyakarta.

\section{Model PAI dalam Rehabilitasi Pecandu Narkoba di Pondok Pesantren Tetirah Dzikir}

Kegiatan pendidikan agama Islam di Panti Rehabilitasi Pondok Tetirah Dzikir melalui tiga tahapan: pertama pra pendidikan, kedua pendidikan agama Islam meliputi pembinaan shalat, puasa, dzikir, qiyamul lail, mandi taubat, ceramah agama, pembelajaran akidah akhlak, fiqih, baca tulis Al-Qur'an, dan ketiga adalah pendidikan pasca sembuh. Pada tahap pra pendidikan, aktivitas yang dilakukan adalah: (1) penyerahan klien oleh wali atau orang tua kepada pengasuh pondok pesantren; (2) diagnosis tingkat kecanduannya terhadap narkoba. Hal ini diperlukan untuk penempatan pemondokan klien; dan (3) dukungan wali atau orang tua, baik dukungan dana pendidikan maupun dukungan pemberian lingkungan yang memadai pada saat klien menjalani proses rehabilitasi.

\footnotetext{
"Tahap pendidikan agama Islam dalam rehabilitasi para pecandu narkoba di pesantren ini terdiri dari: 1) Pendidikan shalat, meliputi shalat wajib dan sunnah, mulai dari cara wudhu, cara shalat, baik bacaan maupun gerakan sampai cara shalat berjamaah; 2) Pendidikan puasa, baik puasa wajib maupun sunnah, klien dilatih betul untuk dapat mendekatkan diri kepada Allah melalui ibadah puasa. Lama kelamaan klien akan menyadari kesalahan-kesalahannya selama ini sehingga benar-benar taubat; 3) Pendidikan dzikir.." 39
}

\footnotetext{
${ }^{38}$ Zuhairini, dkk., Filsafat Pendidikan Islam, 32.

${ }^{39}$ KH. Muhammad Trihardana, Wawancara, Sleman, 27 Januari 2020.
} 
Dalam ajaran Tarekat Qadiriyah wa Naqsyabandiyah di Pondok Pesantren ini terdapat 2 (dua) jenis dzikir yaitu: Pertama, dzikir nafi isbat yaitu dzikir kepada Allah dengan menyebut kalimat “lailahaillallah”. Dzikir ini merupakan inti ajaran Tarekat Qadiriyah yang dilafadzkan secara jahr (dengan suara keras). Dzikir nafi isbat pertama kali dibaiatkan kepada Ali ibn Abi Thalib pada malam hijrahnya Nabi Muhammad dari Mekah ke kota Yasrib (madinah) di saat Ali menggantikan posisi Nabi (menempati tempat tidur dan memakai selimut Nabi). Dengan talqin dzikir inilah Ali mempunyai keberanian dan tawakaal kepada Allah yang luar biasa dalam menghadapi maut. Alasan lain Nabi membaiat Ali dengan dzikir keras adalah karena karakteristik yang dimiliki Ali. la seorang yang periang, terbuka, serta suka menentang orang-orang kafir dengan mengucapkan kalimat syahadat dengan suara keras.

Kedua, dzikir ismu dzat yaitu dzikir kepada Allah dengan menyebut kalimat “Allah" secara sirr atau khafi (dalam hati). Dzikir ini juga disebut dengan dzikir latifah dan merupakan ciri khas dalam Tarekat Naqsyabandiyah. Sedangkan dzikir ismu dzat dibaiatkan pertama kali oleh Nabi kepada Abu Bakar al-Siddiq, ketika sedang menemani Nabi di Gua Tsur, pada saat berada dalam persembunyiannya dari kejaran para pembunuh Quraisy. Dalam kondisi panik Nabi mengajarkan dzikir ini sekaligus kontemplasi dengan pemusatan bahwa Allah senantiasa menyertainya.

Berdasarkan hasil wawancara dengan Ustadz M. Sulkhan Taufik, ada 12 adab yang harus diperhatikan di saat melakukan dzikir yaitu: 1) Duduk di tempat suci seperti shalat. 2) Meletakkan kedua telapak tangan diatas kedua pahanya. 3) Mengharumkan tempatnya untuk berdzikir. 4) Memakai pakaian yang halal dan suci. 5) Memilih tempat yang gelap dan sepi. 6) Memejamkan kedua mata. 7) Membayangkan pribadi guru mursyidnya. 8) Jujur dalam berdzikir. 9) Ikhlas. 10) Memilih shighot Laa ilaaha illallah. 11) Menghadirkan makna dzikir di dalam hatinya. 12) Mengosongkan hati dari segala apapun selain Allah. Sedangkan tiga adab setelah berdzikir adalah: 1) Bersikap tenang dan khusyu. 2) Mengulang-ulang pernafasannya berkali-kali. 3) Menahan minum air. ${ }^{40}$

Secara lebih khusus, KH. Muhammad Trihardana, memaparkan bahwa model pendidikan agama Islam dalam rehabilitasi pecandu narkoba di pondok pesantren Tetirah Dzikir Sleman Yogyakarta terdiri dari beberapa kegiatan sebagai berikut: ${ }^{41}$

1. Qiyamul lail

Qiyamul lail ialah shalat yang dikerjakan pada waktu malam dengan shifat, kaifiyat dan rakaat tertentu sesuai dengan tuntunan Allah dan Rasul-Nya. Berkenaan

40 Ustadz M. Sulkhan Taufik, Wawancara, Sleman, 22 Januari 2020.

${ }^{41} \mathrm{KH}$. Muhammad Trihardana, Wawancara, Sleman, 22 Januari 2020. 
dengan qiyamul lail ini Allah berfirman dalam Al-Furqon : 63-64 yang artinya : "Dan hamba-hamba Allah yang Maha penyayang (ialah) mereka yang berjalan di permukaan bumi ini dengan merendah diri, dan apabila orang-orang jahil mengajak mereka berbicara (dengan perkataan yang tidak sopan), mereka menjawab dengan perkataan yang sopan. Dan mereka itu apabila pada waktu malam hari bersujud dan berdiri (shalat) karena (ikhlas) kepada Tuhan mereka."

2. Mandi Taubat

Mandi adalah mengalirkan air suci mensucikan ke seluruh tubuh atau hakikat mandi yaitu mengguyur seluruh badan dengan air, yaitu mengenai rambut dan kulit. Dasar hukumnya adalah firman Allah dalam Surah Al-Baqarah:222 yang artinya: "Sesungguhnya Allah menyukai orang-orang yang bertaubat dan menyukai orangorang yang mensucikan diri."

“..Terapi mandi adalah suatu penyembuhan atau usaha jiwa guna mensucikan dirinya (thaharah) dengan mengalirkan air suci mensucikan ke seluruh tubuh sehingga mampu memberi solusi dari problem kejiwaan setiap manusia dan menjadi sadar akan dirinya sehingga lebih berkonsentrasi dalam menjalankan ibadah serta mendekatkan diri kepada Allah..." 42

Terapi merupakan pengobatan alam pikiran atau lebih tepatnya perawatan dan pengobatan gangguan psikis melalui metodologi psikologis. Adapun tujuan terapi antara lain (1) menghilangkan atau mengubah gejala penyakit mental, (2) memperantarai (perbaikan) tingkah laku yang rusak, (3) meningkatkan pertumbuhan dan perkembangan kepribadian yang positif. ${ }^{43}$ Pendidikan mandi sebagai terapi yang dilakukan dalam penelitian ini untuk tahap persiapan: (1) Penyiapan sarana mandi; (2) Membangunkan para klien; (3) Membaca do'a masuk kamar mandi. Tahap pelaksanaan: (1) Niat mandi; (2) Berwudhu; (3) Menyiramkan air ke seluruh tubuh. Pada tahap penutupan dilakukan kegiatan: (1) Membaca do'a keluar kamar mandi; dan (2) Pemberian sugesti dari terapis.

3. Ceramah Agama

Kegiatan ini dilaksanakan setiap malam Jumat, diisi oleh pengasuh pondok dan kadang-kadang mantan klien yang sudah sembuh total dan menjadi relawan di pondok membantu pengasuh pondok melakukan terapi kepada klien-klien baru. Adapun pendidikan akidah akhlak, fiqih, dan baca tulis Al-Qur'an dilaksanakan secara klasikal pada klien yang telah dinyatakan sembuh, namun masih perlu perawatan.

42 KH. Muhammad Trihardana, Wawancara, Sleman, 22 Januari 2020.

43 Baharuddin \& Mulyono, Psikologi Agama, dalam Perspektif Islam (Malang: UIN Maulana Malik Ibrahim Malang Pres, 2008), 159 
Setelah berbagai pendidikan dan terapi diikuti klien dan klien dinyatakan sembuh, kemudian dilakukan pendidikan pasca sembuh sampai klien diperbolehkan pulang atau menjadi relawan di pondok pesantren Tetirah Dzikir Sleman Yogyakarta. ${ }^{44}$ Model rehabilitasi pecandu narkoba di Pondok Panti Rehabilitalisi Berbah Sleman ini sejalan dengan yang dilakukan di Pondok Pesantren Suryalaya Tasikmalaya. Lestari ${ }^{45}$ menemukan bahwa pembinaan dan penyadaran korban penyalahgunaan NAPZA dilakukan melalui metode Zikrullah, yang dimaksud sebagai upaya untuk menenangkan hati, menyembuhkan segala penyakit hati, membersihkan hati, dan sebagai sarana meningkatkan keimanan kepada Allah. Materi rehabilitasi meliputi mandi malam atau bertaubat, shalat wajib dan sunnah, dzikir, membaca Al-quran, riyadlah, pengajian mingguan dan bulanan, dan pembelajaran tentang hal-hal ilmiah seperti fiqh, tauhid, akhlaq, dan tashawuf.

Proses rehabilitasi pecandu narkoba di pesantren pada umumnya murni menggunakan pendekatan religi. Berbeda halnya dengan temuan Hawi ${ }^{46}$ yang mengintegrasikan pendepatan medis, psikologis dan religi. Temuan penelitiannya bahwa proses rehabilitasi remaja pecandu narkoba di Panti Rehabilitasi Narkoba Pondok Pesantren Ar-Rahman Palembang, dilakukan dengan cara mengintegrasikan model terapi fisiologis yang berbasis medis, model psikoterapi yang berbasis psikologi dan model terapi moral yang berbasis spiritual, diikuti dengan pengembangan kemampuan interaksi sosial, pemberian kekebalan jiwa dalam menghadapi pengaruh negatif lingkungan sosial yang baru, serta keterampilan hidup (life skill) sebagai bekal mereka menjalani kehidupan pasca rehabilitasi. Adapun tahapan rehabilitasi tersebut, dimulai dari penyembuhan secara medis ganguan fisik yang diderita remaja binaan, dilanjutkan dengan penyembuhan ganguan psikis, kemudian jiwa mereka diisi dengan nilai-nilai spiritual, sebagai basis kekuatan jiwa yang dapat menumbuhkan kesadaran mereka, untuk meraih bentuk kehidupan baru yang religius, sehat dan kereatif serta terhindar dari pengaruh sosial yang negatif.

\section{E. Kesimpulan}

Dasar pemikiran pentingnya rehabilitasi pecandu narkoba menggunakan pendidikan agama Islam di Pondok Pesantren Tetirah Dzikir Berbah Sleman Yogyakarta

\footnotetext{
${ }^{44}$ Ustadz Ahmad Shobary, Wawancara, Sleman, 25 Januari 2020.

45 Lestari "Metode Terapi dan Rehabilitasi Korban NAPZA di Pondok Pesantren Suryalaya Tasikmalaya".

46 Akmal Hawi. "Remaja Pecandu Narkoba: Studi tentang Rehabilitasi Integratif di Panti Rehabilitasi Narkoba di Pondok Pesantren Ar-Rahman Palembang”, Tadrib: Jurnal Pendidikan Agama Islam, Vol. 4, No. 1 (Juli 2018).
} 
meliputi: pertama, dasar yuridis meliputi: (1) dasar ideal tertuang dalam sila pertama pancasila: ketuhanan yang maha Esa; dan (2) dasar struktural tercantum dalam bab XI pasal 29 ayat 1 dan 2 UUD 1945 dan UU No 22 Tahun 1997 pasal 49. Kedua, dasar religus, yakni: (1) keyakinan bahwa pendidikan agama merupakan perintah Tuhan dan perwujudannya merupakan ibadah kepadaNya sebagaimana QS. An Nahl [16] :125; (2) Larangan Allah meminum khamer sebagaimana firman Allah dalam QS Al-Maidah ayat 90; dan perintah Allah kepada hambanya untuk menyuruh kepada perbuatanperbuatan kebaikan dan mencegah kemungkaran sebagaimana QS. Al Imran [3]:104. Ketiga, dasar psikologis, yaitu dasar yang berhubungan dengan aspek kejiwaan kehidupan bermasyarakat. Model Pendidikan Agama Islam dalam rehabilitasi pecandu narkoba di Pondok Pesantren Tetirah Dzikir Berbah Sleman Yogyakarta dilakukan melalui tiga tahapan: pertama pra pendidikan, kedua pendidikan agama Islam meliputi pembinaan shalat, puasa, dzikir, qiyamul lail, mandi taubat, ceramah agama, pembelajaran akidah akhlak, fiqih, baca tulis Al-Qur'an, dan ketiga adalah pendidikan pasca sembuh.

Penulis berargumen bahwa selain pengobatan dan atau perawatan melalui rehabilitasi medis, proses penyembuhan pecandu narkoba dapat ditopang melalui pendekatan keagamaan dan tradisonal yang dapat diselenggarakan oleh masyarakat secara mandiri. Perlu ditegaskan, ada beberapa hal yang harus diperhatikan: pertama, perlu adanya perhatian orang tua atau wali klien, baik berupa dukungan moral kepada pasien atau dukungan finansial kepada pondok pesantren. Kedua, pemerintah setempat harus mendukung penuh kegiatan di Pondok Pesantren Tetirah Dzikir Berbah Sleman ini. Karena rehabilitasi berbasis pendidikan agama Islam pondok pesantren tersebut merupakan upaya opsional yang membantu pemerintah untuk meminimalisir bahkan menyembuhkan efek negatif narkoba kepada para penggunanya. Ketiga, masyarakat sekitar rumah klien yang telah dinyatakan sembuh, harus menerima kembali mereka sebagai bagian dari anggota masyarakat yang mempunyai hak dan kewajiban yang sama.

\section{F. Referensi}

Adz-Dzaky, M. Hamdani Bakran. Konseling dan Psikoterapi Islam. Yogyakata: Fajar Pustaka Baru, 2004.

Alhamuddin. "Merawat Jiwa Menjaga Tradisi : Dzikir Dan Amal Thariqah Qadiriyah Naqsabandiyah Dalam Rehabilitasi Korban Napza Sebagai Terapis Ala Islam Nusantara." Sosial Budaya: Media Komunikasi Ilmu-ilmu Sosial dan Budaya, Vol. 
12, No. 1 (Januari-Juni 2015.

Ali, Mansur. "Perspectives on Drug Addiction in Islamic History and Theology." Religions, Vol. 5 (2014).

Aqib, Kharisudin. Inabah Jalan Kembali dari Narkoba, Stress dan Kehampaan Jiwa. Surabaya: PT. Bina Ilmu, 2005.

AR, Zaini Tamin dan Subaidi. "Implementasi Segregasi Kelas Berbasis Gender dalam Menaggulangi Interaksi Negatif Siswa di SMP Al-Falah Ketintang Surabaya”. Al Hikmah : Jurnal Studi Keislaman, Vol. 9, No. 1 (2019): 30-43.

Az-Zaibairi, Amir Said. Manajemen Qalbu. Yogyakarta: Pustaka Pelajar, 2003.

Badan Narkotika Nasional. Mencegah Lebih Baik dari pada Mengobati. Jakarta: Team BNN, 2013.

Baharuddin \& Mulyono. Psikologi Agama, dalam Perspektif Islam. UIN. Malang Pres, 2008.

Depag RI. Alqur'an Dan Terjemahnya. Bandung: SYGMA, 2009.

Firdaus, Ismet. "Meta Analisis Hasil Penelitian Model-Model Rehabilitasi Narkoba oleh Lembaga Pemerintah, Masyarakat dan Pesantren di Jabodetabek." EMPATI: Jurnal Ilmu Kesejahteraan Sosial, Vol. 4 No. 1 (Juni 2015).

Hawari, Dadang. Al-Qur'an dan Ilmu Kedokteran Jiwa dan Kesehatan Jiwa. Yogyakarta: Dana Bhakti Prima Yasa, 2007. . Do'a dan Dzikir sebagai Pelengkap Terapi Medis. Yogyakarta: PT. Dana Bakti Prima Yasa, 2003.

Penyalahguna dan Ketergantungan NAZA (Narkotika, Alkohol, dan Zat Adiktif). Jakarta: Penerbit FKUI, 2006.

Hawi, Akmal. "Remaja Pecandu Narkoba: Studi tentang Rehabilitasi Integratif di Panti Rehabilitasi Narkoba di Pondok Pesantren Ar-Rahman Palembang". Tadrib: Jurnal Pendidikan Agama Islam, Vol. 4 No. 1 (Juli 2018). DOI: $\underline{10.19109 / T a d r i b . v 4 i 1.1958}$

Kadarmanta. Narkoba Pembunuh Karakter Bangsa. Jakarta: PT Forum Media Utama, 2010.

Lestari, Puji. "Metode Terapi dan Rehabilitasi Korban NAPZA di Pondok Pesantren Suryalaya Tasikmalaya." Socia: Jurnal Ilmu Sosial, Vol. 10, No. 2 (September 2013).

Lisa, Juliana dan Sutrisna, Nengah. Narkoba, Psikotropika dan Gangguan Jiwa. Tinjauan Kesehatan dan Hukum. Yogyakarta: Nuha Medika, 2013.

Majid, Abdul dan Andayani, Dian. Pendidikan Agama Islam Berbasis Kompetensi: Konsep dan Implementasi Kurikulum 2004. Bandung: PT Remaja Rosdakarya, 2006.

Muhtar. "Pendekatan Spiritual dalam Rehabilitasi Sosial Korban Penyalahgunaan 
Narkoba di Pesantren Inabah Surabaya”. INFORMASI Vol. 19, No. 3 (September Desember, 2014).

Nata, Abuddin. Ilmu Kalam Filsafat dan Tasawuf. Jakarta: PT. Raja Grafindo Persada, 2001.

Rajab, Khairunnas. "Methodology of Islamic psychotherapy in Islamic boarding school Suryalaya Tasik Malaya." IJIMS: Indonesian Journal of Islam and Muslim Societies, Volume 4, Number 2 (December 2014).

Ramayulis. Ilmu Pendidikan Islam. Jakarta: Kalam Mulia, 2013.

Rokib, Abdur. "Penyembuhan Pecandu Narkoba dan Stress di Pondok Sapu JagadYayasan Pesantren Raudlatul Ulum Kencong, Kepung, Kediri, Jawa Timur”. Tesis------Pascasarjana IAIN Sunan Ampel Surabaya, 2009.

Tafsir, Ahmad. Ilmu Pendidikan Islami. Bandung: PT Remaja Rosdakarya, 2012.

Tawil, Madjid dkk. Narkoba Dikenal untuk Dijauhi. Surabaya: BNP JATIM, 2005.

Tim Prima Pena. Kamus Ilmiah Populer. Surabaya: Gitamedia Press, 2006.

Zuhairini, dkk. Filsafat Pendidikan Islam. Jakarta: Bumi Aksara, 2009.

\section{Hasil Wawancara}

KH. Muhammad Trihardana, Wawancara, Sleman, 22 Januari 2020.

Ustadz Ahmad Shobary, Wawancara, Sleman, 25 Januari 2020.

Ustadz M. Sulkhan Taufik, Wawancara, Sleman, 22 Januari 2020.

Ustadz Muhammad Ismail, Wawancara, Sleman, 11 Januari 2020. 